\title{
Natural black pine (Pinus nigra subsp salzmannii) forests of the lberian eastern mountains: development of the phytoecological basis for their site evaluation *
}

\author{
P Regato-Pajares ${ }^{1}$, R Elena-Rosselló ${ }^{2}$
}

1 Centro de Investigación Forestal, INIA, apartado 8111, Madrid;

2 Departamento de Silvopascicultura, Universidad Politecnica de Madrid, 28040 Madrid, Spain

(Received 2 January 1994; accepted 2 January 1995)

\begin{abstract}
Summary - A phytoecological study of the Pinus nigra subsp salzmannii forests in the dolomitelimestone mountains of eastern Spain was undertaken. Starting from several floristic and ecological data collected from 355 relevés, classification and ordination numerical analysis were realized. A typification of the different pine forest communities was thus obtained and a series of floristic groups was defined, which can be used as a basis for the classification of distinct sites. Following the phytosociological method, 2 main groups, which can be considered as climax vegetation of the high supra- and mountain-Mediterranean levels, have been defined: a continental group, Thalictro tuberosi-Pinetum salzmannii, and a subcontinental group, Lonicero xylostei-Pinetum salzmannii, which represents the southern range limit of Pinus nigra forests in the eastern Pyrenees.
\end{abstract}

Pinus nigra / numerical analysis / phytosociology / climax / floristic group

Résumé - Typologie phytoécologique des stations forestières : les forêts naturelles de pin de Salzmann (Pinus nigra subsp salzmanni) des montagnes orientales ibériques. La présente étude concerne la caractérisation phytoécologique des forêts de Pinus nigra subsp salzmannii des montagnes orientales de l'Espagne. Des analyses numériques de classification et ordination ont été réalisées avec 355 relevés comprenant des données floristiques et écologiques. La typologie des différents groupements silvatiques de Pinus salzmannii a permis d'établir plusieurs groupes floristiques, susceptibles d'être utilisés dans la caractérisation des stations forestières de cette essence. Selon la méthode phytosociologique, ont été distinguées 2 associations qui représentent sûrement la végétation climatique à l'horizon supérieur de l'étage supraméditerranéen et à l'étage montagnard-méditerranéen : Thalictro tuberosi-Pinetum salzmannii dans la partie occidentale avec des conditions cli-

* The present work complies with the nomenclature given in Bolos et al (1990), Castroviego et al (1986-1993) or Tutin et al (1964-1980). 
matiques méditerranéo-continentales, et Lonicero xylostei-Pinetum salzmannii dans la partie orientale avec des conditions climatiques sub-continentales. Les forêts de pin de Salzmann qui appartiennent à la dernière association représentent la limite méridionale de ce groupement caractéristique des Pyrénées orientales.

Pinus nigra / analyse numérique / phytosociologie / climat / groupe floristique

\section{INTRODUCTION}

Pinus nigra subsp salzmannii has its central core of distribution in the dolomite-limestone mountain ranges of the eastern portion of the Iberian peninsula (Sistema Ibérico) (fig 1), the main forest region of Mediterranean Spain. Exceptionally a relict population stand isolated in areas of the centralwestern granitic range, representing a special paleogeographic and phytogenetic interest (Regato et al, 1992). The total natural populations of this species extend over approximately 380000 hectares.

The black pine forests found in the Sistema Ibérico account for two-thirds of the total black pine formations in the Iberian peninsula. Together with Pinus sylvestris woods, they represent the most extensive forests of the eastern mountains. While $P$ sylvestris forests have been easily managed, resulting in good even-aged stands, $P$ nigra forests actually have critical problems due in part to the lack of basic understanding about the regeneration biology of this long life species. Furthermore, disturbance processes in the area (geomorphological dynamism, high frequency of storms, etc) generally resulting in uneven-aged stands and the random exploitation of woods, carried out since the beginning of the century, contribute to the present open-structured forests.

Historically, major problems have been encountered when trying to establish a site index for the different types of forests. In particular, when stands are not even-aged, have mixed species compositions or have received severe growth damage, problems with site index are greater (Monserud, 1977).
Therefore, a more ecologically oriented site classification, based on phytosociological concepts and approaches, was developed in an attempt to solve some to these specific problems. As a first attempt, Cajander's approach (1926) defines vegetation types meaningful to forest productivity. After this very early work, other vegetation-oriented studies were conducted (Maycock, 1960; Pfister, 1977; Carleton, 1980; Jeglum et al, 1982; Jones, 1984; Kotar, 1984). All efforts have been conducted to develop a better understanding of natural vegetation patterns in order to establish an ecological classification of forest types. This is the basis for carrying out site evaluation in well-established stands inside each forest type.

In a first attempt to analyze the black pine wood area of Spain, Elena-Rosselló and Sánchez-Palomares (1991) found a good relationship between yield and floristic groups. Given the encouraging results of that early evaluation, a more in-depth analysis in the largest territorial area of $P$ nigra (Sistema Ibérico) was conducted (Regato, 1992) in order to characterize the different habitat types of this species, an essential element to determine the potential productivity of the different sites.

\section{Geobotanical background}

The most important geobotanic studies were conducted by Willkomm $(1844,1852,1896)$, and they provided very accurate descriptions of the main forests of this species. When describing black pine woods along the Sistema Ibérico, he mentioned the exis- 


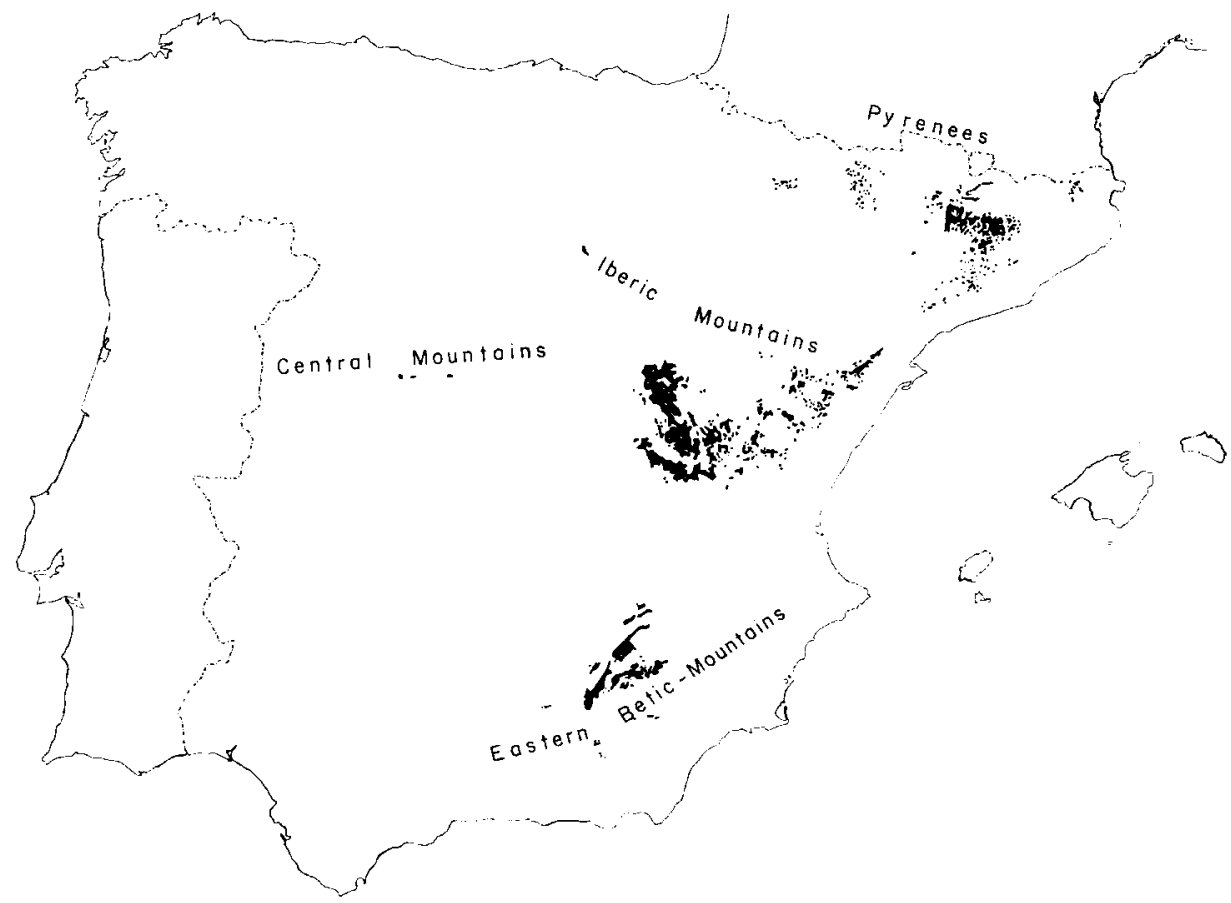

Fig 1. Distribution area of Pinus nigra subps salzmannii in Spain.

tence of pristine forests, which he described as a shady canopy of gigantic trees, including several specimens with an estimated age of more than 1000 years. As far as the structure and degree of development are concerned, he claimed these woods to be perfectly comparable to the best preserved ones in Central Europe. Twenty years later, the same author regretted the serious degradation of these pine woods; today, it is difficult to find mature formations with an average age of more than 150 years.

Since the begining of phytosociological studies in Spain, the role of Spanish Pinus nigra forests has been undervalued, if not neglected. Gaussen (1945) originally defined a potential vegetation series for the Pyrenees, headed by $P$ nigra subsp salzmannii, while Rivas-Goday (1946) described a vegetation level, Pinetum lari- cionis, which is characteristic of the Sistema Ibérico, and located between the upper woods of Pinus sylvestris and the mixed oak forests (Quercus faginea and $Q$ ilex subsp ballota). Nevertheless, such considerations were eventually invalidated, and the sites occupied by the Pinus nigra woods were considered to be either potential oak forests (Quercus faginea, $Q$ pubescens and $Q$ ilex subsp ballota) or potential Juniperus thurifera steppic forests.

Under this prevailing theory, black pine is just an accessory species in such types of forests, and its populations are considered as a consequence of anthropogenic expansion. Thus, a deep phytosociological and ecological study of these pine woods was largely neglected.

Recently, all over western Europe, woods of Pinus nigra subsp salzmannii were reval- 
ued and given greater ecological and phytosociological importance in France (Quezel and Barbero, 1988) and in Spain (Gamisans and Gruber, 1988; Gamisans et al, 1991; Elena-Rosselló and Sánchez-Palomares, 1991; Regato, 1992). Starting from a number of historical elements, as well as the ecological, biogeographic and biological features of this species, it is thought that Pinus nigra subsp salzmannii stands are an important element of the potential vegetation of Spain, defining climatic forests which constitute a special vegetation level. It seems therefore appropriate to revive the initial proposals of Gaussen and Rivas-Goday, and to determine with greater precision the eco- logical value of Pinus nigra in the Spanish vegetation landscape.

\section{Ecological features}

The Sistema Ibérico is a range of mountains with moderate high elevations often over $2000 \mathrm{~m}$, surrounded by high plateaus with an average height of $1200 \mathrm{~m}$. Most of the Pinus nigra forests are located in the supra- and mountain-Mediterranean levels, between 1000 to $1500 \mathrm{~m}$, ranging from the lowest points at roughly $400 \mathrm{~m}$, to the highest ones in the oro-Mediterranean level (fig 2). Under particular conditions and in the

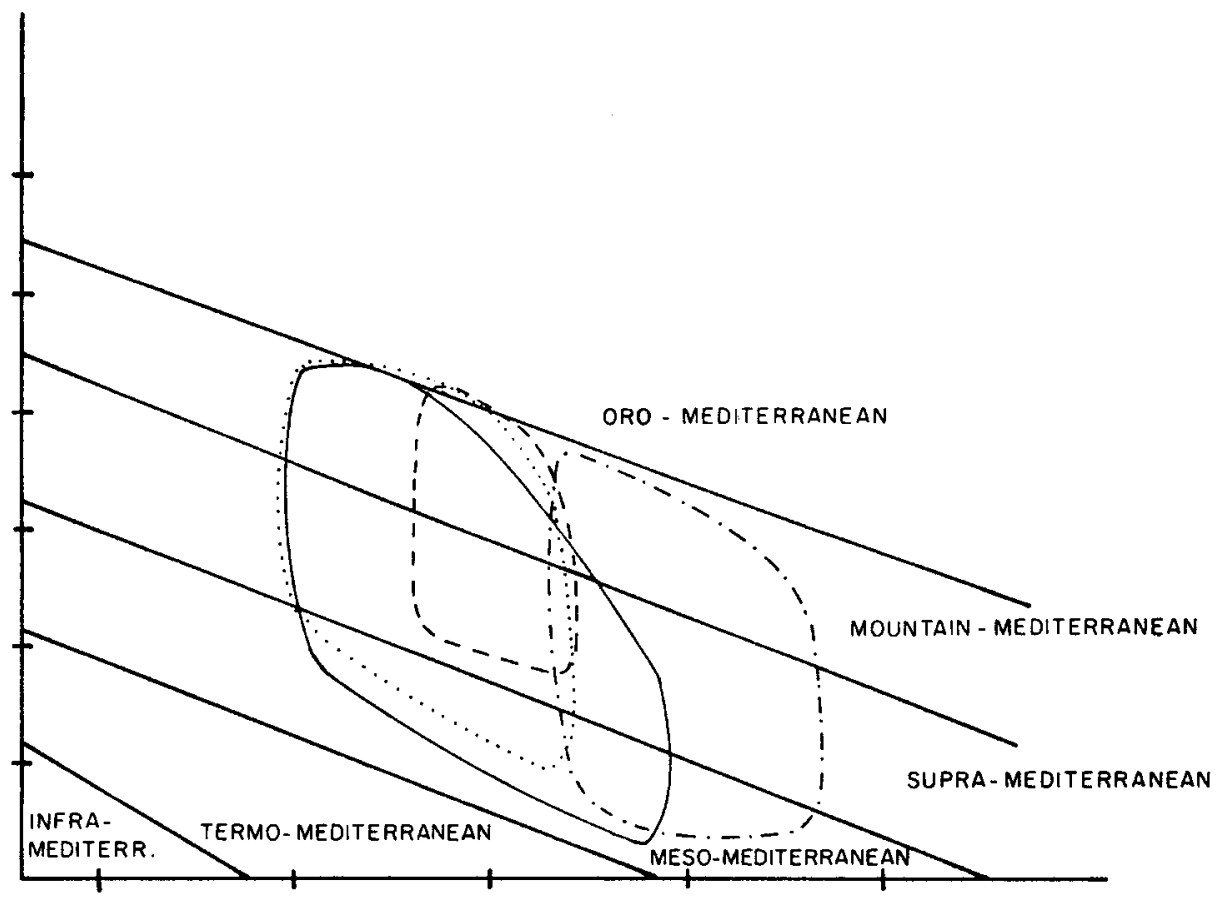

SUBSP. SALZMANNI

SUBSP. PALLASIANA

SUBSP. LARICIO

SUBSP. NIGRA

Fig 2. Diagram of Pinus nigra subspecies relationships in elevation and latitudinal terms. 
southernmost mountains, Sierra de Javalambre, the species reaches the timberline at 1700-1800 m.

While most Spanish ranges have a west to east orientation, the Iberic Mountains cross the eastern part of the peninsula from north to south, representing a barrier to the main northwestern rain fronts. As a consequence, the climate becomes highly continental to the core of this mountainous region and results in different characteristics of the water regime between the Mediterraneanand the inner face of these mountains.

The physiography of these mountains is particularly affected by the alternance of different lithological types. Karstic elevations prevail, and doline fields, lapiaces and river canyons are frequent. Gravity slopes, upland rocky plains and ridges are mainly made of more or less pure dolomites, while slopes and the floor of the valley are of different lithologic types (limestone, dolomites, marls, sandstone and gypsum), which influence the slope profile.

Soils are poorly developed and mostly superficial, with a prevalence of the rendzina-type (Sánchez-Palomares et al, 1990). According to these authors, in spite of the degree of soil evolution of the black pine woods area, these should be considered as mainly mature, as they represent the edaphic potentiality of such mountains. The abundance of dolomites, which typically have a difficult chemical weathering, makes soil evolution even more difficult.

From the climatic point of view (Regato, 1992), the areas where these pine woods are mainly found have humid and subhumid types of bioclimates, in their "cold" and "very cold" variations (according to Emberger's classification in Daget, 1977) (fig 3). Exceptionally, they can also be found in a semi-arid superior cold bioclimate, corresponding to the lower and more continental areas of its distribution range. According to Allue-Andrade's classification (1990), black pine woods are to be found mainly in the
nemoro-Mediterranean humid (VI(IV)2) and substeppic nemoral (VI(VII)) phytoclimatic types. The most xeric nemoro-Mediterranean type (VI(IV)1) would roughly correspond with the semi-arid bioclimate typical of the lower and most continental areas.

Continentality is remarkable, with winter mean minima temperature as low as $-7^{\circ} \mathrm{C}$ and absolute minima reaching values of $-25^{\circ} \mathrm{C}$. The frost-free season can be as short as 1 mid-summer month, which also tends to be characterized by a more or less acute hydric deficiency. Under such extreme conditions, the vegetative period is considerably short and, as stated by Walter (1968), evergreen coniferous species take the place of broad-leaf marcescent species.

\section{MATERIALS AND METHODS}

Data from 355 forest sites were collected over the full geographic range of Pinus nigra in the Sistema Ibérico (Regato, 1992). The sampling method used, that is, preferential sampling (Gauch, 1982), subjectively selects sample sites that appear to be homogeneous and distributes them equitably throughout the black pine study area according to the altitudinal range and to the geomorphological variability. The phytosociological relevés were made using the Braun-Blanquet method (1951). Each relevé represented a comparatively homogeneous area, generally from $200-400 \mathrm{~m}^{2}$. Species' cover-abundance values were transformed according to Van der Maarel (1981). Elevation, slope, aspect and proportion of rocks in the surface were calculated for each relevé. Potential solar radiation was calculated using latitude, aspect and slope (Gandullo, 1974).

Polythetic divisive classification was conduced with TWINSPAN (Hill, 1979) on a data matrix comprising 355 sites $\times 550$ species (Regato, 1992). Subsequently, all final TWINSPAN dichotomies were explored by detrended correspondence analysis (DCA) (Hill and Gauch, 1980) and canonical correspondence analysis (CCA) (Ter Braak, 1988) to determine to which extent the dichotomies reflected a discontinuity in the site floristic data and their relations with certain variables (Regato, 1992). 


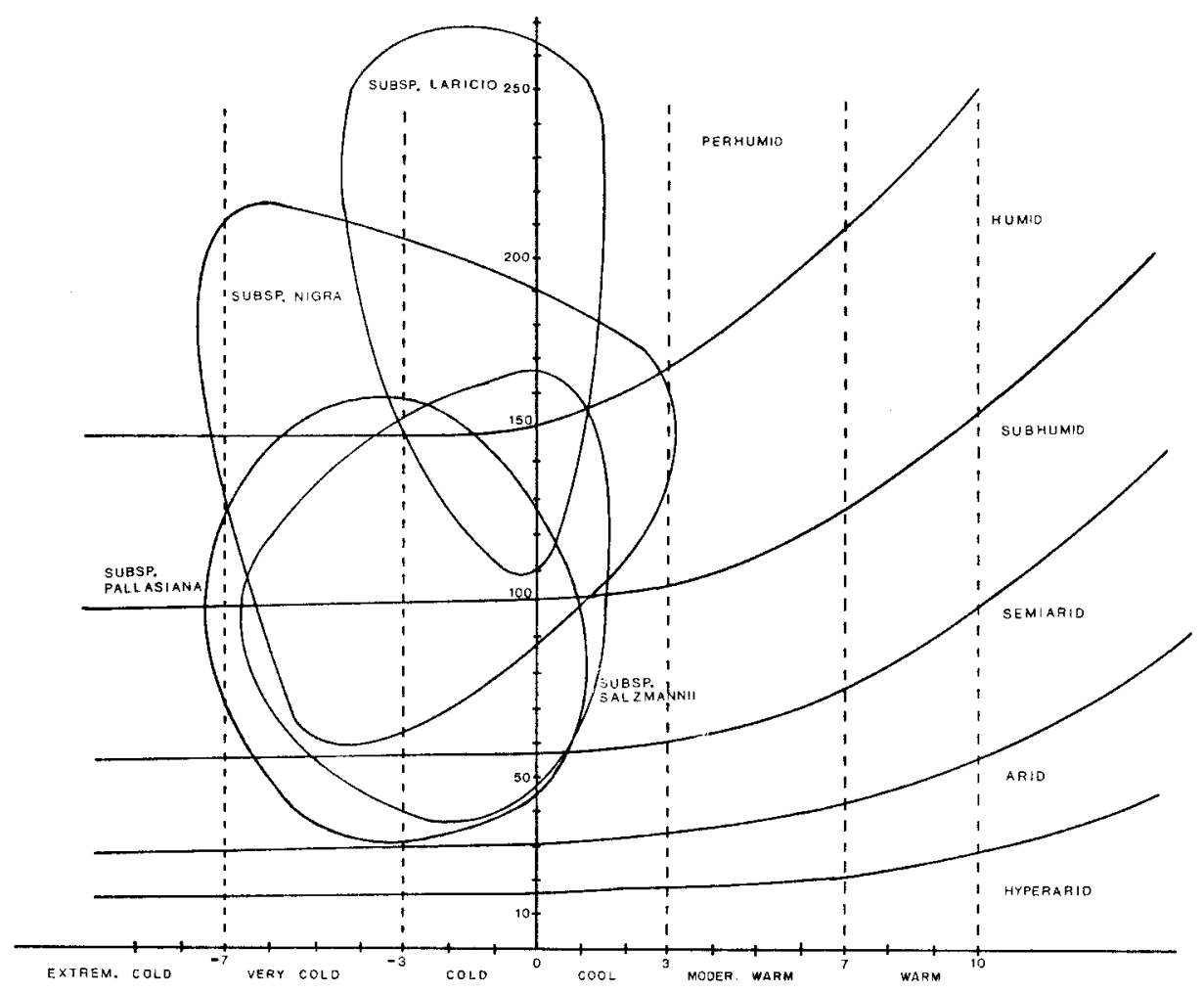

Fig 3. Emberger diagram showing the bioclimatical level ranges of the different subspecies of Pinus nigra.

\section{RESULTS}

The TWINSPAN classification analysis resulted in 27 different floristic groups. Subsequently, all final TWINSPAN dichotomies were explored using DCA and CCA. On the basis of these ordination analyses, 13 floristic groups were definitively established. The reduction from the initial 27 group classification to the final 13 group classification is represented in figure 4 .

The resulting 13 groups are ranked in the dendrogram according to a xerothermic gradient. The first dichotomy in TWINSPAN classification hierarchy distinguishes between black pine forests associated with sites of mesophilous conditions (cooler and wetter), and generally located at the highest altitude (ranging between 1100 to 1500 $\mathrm{m})$, and black pine forest associated with more xerothermic sites (ranging between 900 to $1100 \mathrm{~m}$ ).

Some typical species of the bushy formations of the area, Thymus vulgaris, Lavandula latifolia and Koeleria vallesiana, appear as nonindicative of the 2 groups that result in the first division (fig 4). This suggests a certain degradation of the understory in most black pine woods, particularly those that are subject to heavy timber exploitation. Furthermore, the subrupiculous nature of many of these woods also 


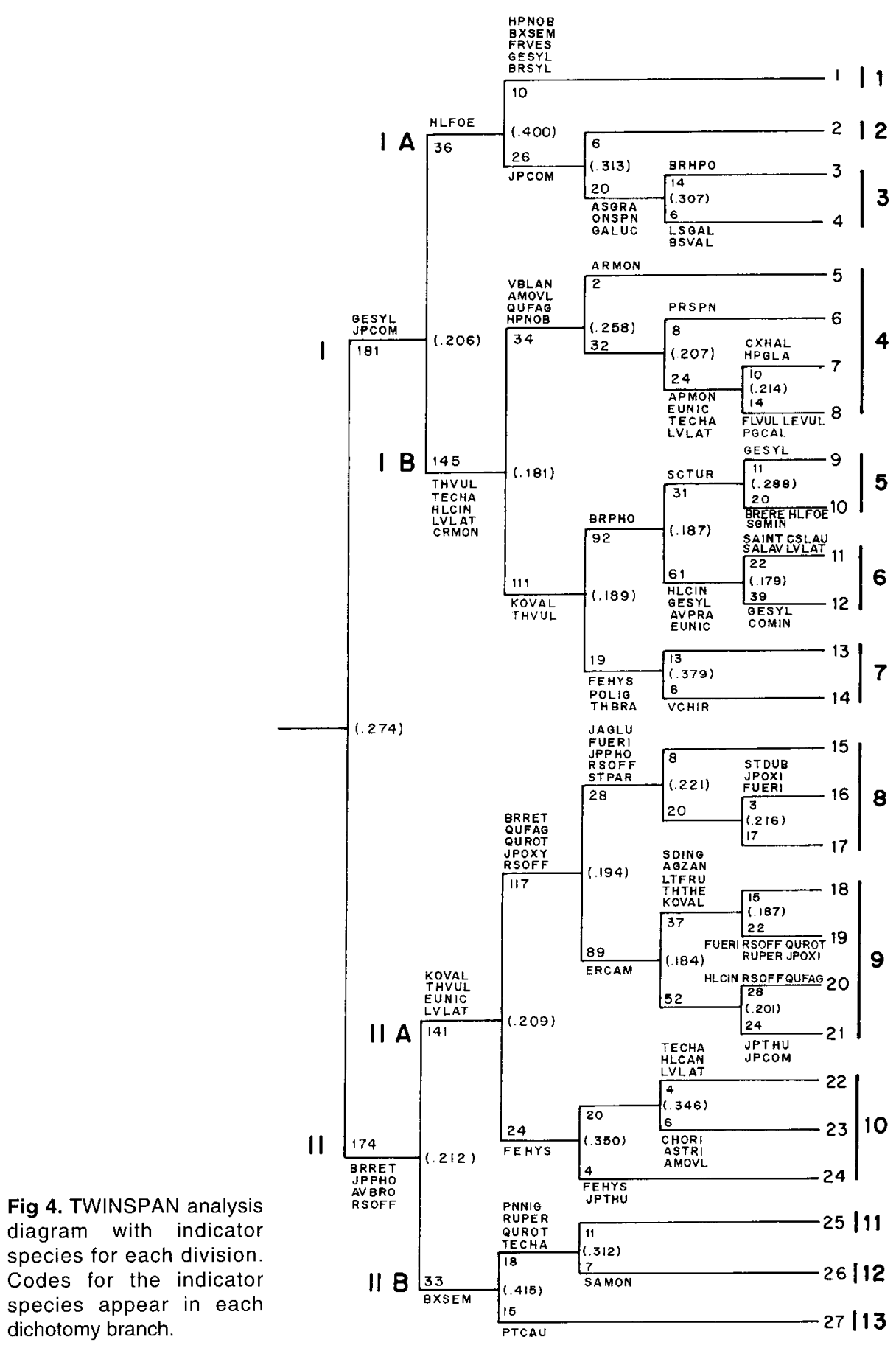


contributes to the presence of these species characteristic of open scrub communities.

In the second division level of the classification, both mesophytic and xerothermic sites are divided into 2 groups: a more continental group typical of the inner mountains (western sector), and another group with subcontinental character typical of the ranges closer to the Mediterranean Sea (eastern sector) (fig 4).

These 4 groups resulting from the second tier are separately located in the 4 quarters of the DCA diagram, defined by the first 2 axes. Axis 1 represents a xerothermic gradient, while axis 2 represents a continentality gradient. Therefore, those black pine forests which have good mesophyllous conditions and are typical of the most advanced phases appear towards the negative values of the axis 1 , while those forests which have a more sparse structure appear towards the positive values of the axis (fig 5), being typical of lowest xerothermic areas, where $P$ nigra is found at the limits of its distribution, or of degraded areas where more xerophytic species colonize the subcanopy.

In the CCA ordination analysis, groups resulting from subsequent divisions of the TWINSPAN classification analysis are the best defined. Such groups are associated to sites with a high proportion of rocky substrates and steep slopes, both factors strongly associated with axis 2 . An altitudinal gradient becomes apparent along the axis 1 (fig 6).

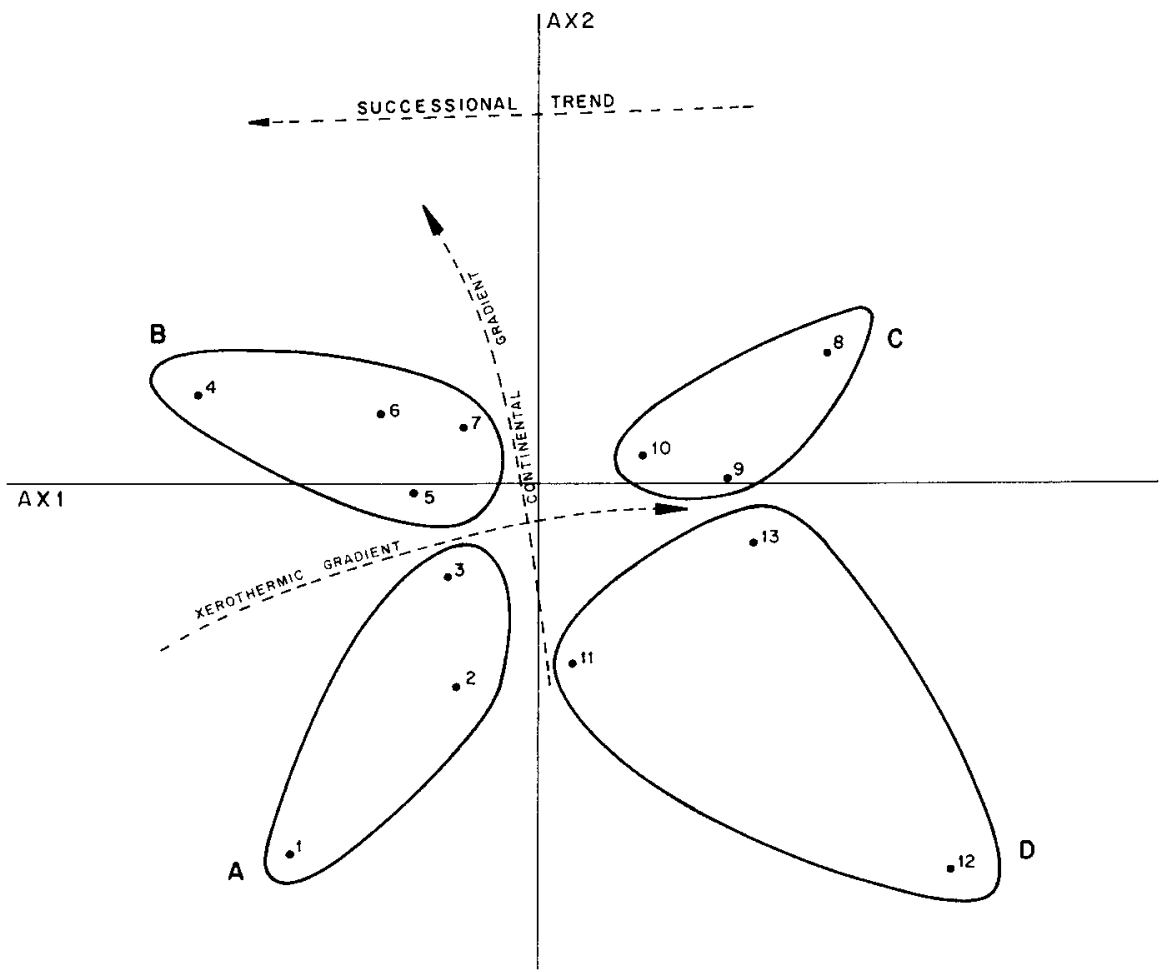

Fig 5. DCA analysis diagram. Numbers indicate the situation of the 13 TWINSPAN site groups. Arrows show the underlying ecological factors. Capital letters indicate the 4 site groups established at the TWINSPAN second level. 


\section{Mesophytic black pine woods of the eastern sector: groups 1-3}

This grouping includes 40 sites associated to the highest altitude zones of the eastern mountains characterized by the lowest continentality. Frequently, its sites are located in the ubacs, where the comparatively higher air relative moisture attenuates their thermic continentality. Their phytoclimatic type, located between 1000 and $1700 \mathrm{~m}$ of altitude, is humid nemoro-Mediterranean (VI(IV)2) or substeppic nemoral (VI(VII)). Dolomite substrates are predominant. Sites in groups $1-3$ are located mostly in the lower left quarter of the DCA diagram.

Group 1: includes forest formations well vertical-structured and developed, with nemoral understory, that can be considered as climax vegetation of the high supra- and low mountain-Mediterranean level of the dolomite-limestone mountains of the western Iberian system (Puertos de Beceite, Maestrazgo and western stations of Gudar and Javalambre sierras). A group of subMediterranean and eurosiberian species characterizes both the scrub and the herbaceous layers, belonging to Quercetalia pubescentis, or in a wider scope, to QuercoFagetea. Indicator and preferential species are Primula veris subsp columnae, Hepatica nobilis, Brachypodium sylvaticum, Fragaria vesca, Pteridium aquilinum, Acer opalus subsp granatense, Sorbus aria, Buxus sempervirens, llex aquifolium, among others. Mixed forest formations with Pinus sylvestris, characteristic of the upper forest level, are very often defined. Due to floristic similarities of black pine woods in this zone with the woods described in the Pyrenees (Gamisans and Gruber, 1988), it can be considered that both belong to the same association, Lonicero xylostei-Pinetum salz-

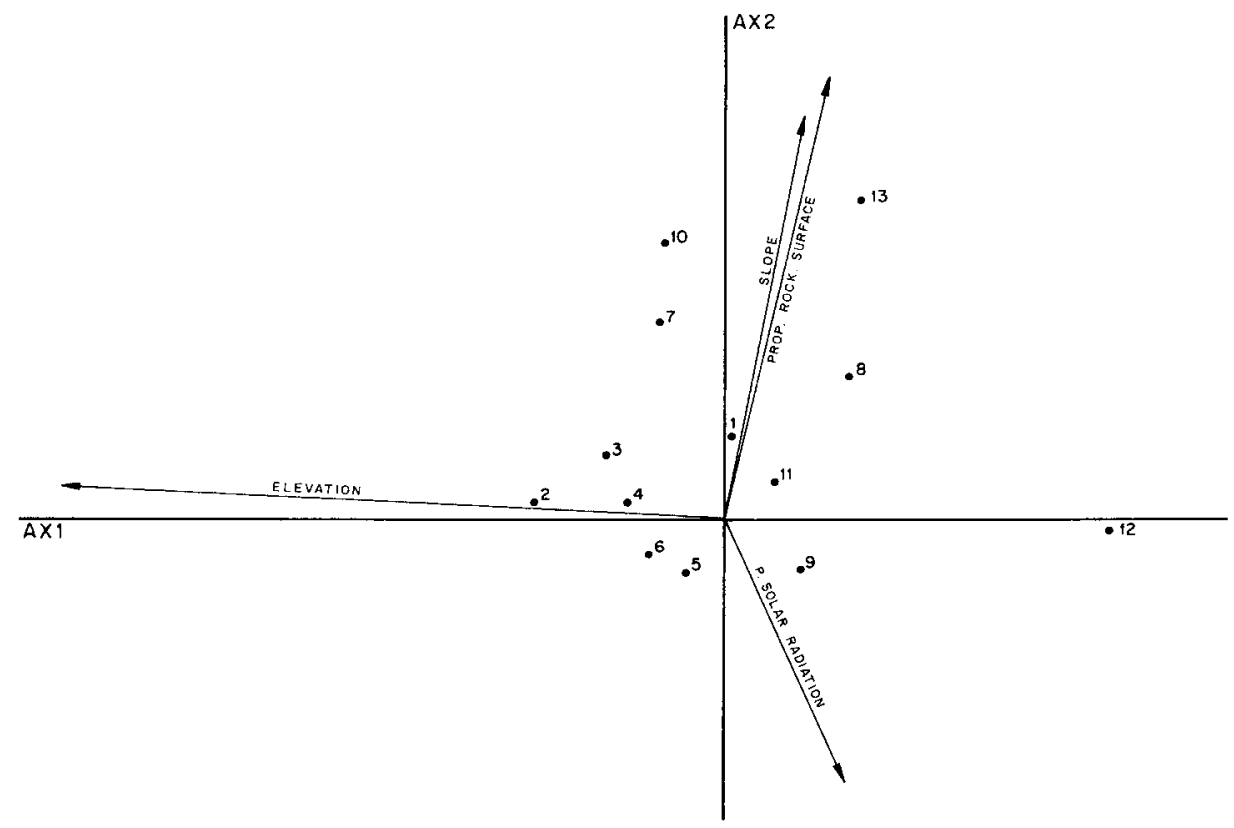

Fig 6. CCA analysis diagram. The situation of the 13 TWINSPAN site groups is indicated by a number. Arrows indicate environmental physical gradients. The isolines suggest 3 groups of site quality: good (I); medium (II); and poor (III). 
mannii (table I). Therefore, black pine woods in this group may be a southern expansion from the Pyrenees formations, and represent a transition from these to the more continental ones. Furthermore, some typically Pyrenean species are found in the understory, and they are representative of their southern limit (Lavandula angustifolia and Teucrium pyrenaicum).

Group 2: comprises forest formations with an open structure that define the timberline of the western slopes of Javalambre and Camarena sierras, towards Teruel, with cold and xeric continental climate. These sites are located in the transitional zone from the forest of the more continental western sector to the eastern sector, and therefore their characterization is sometimes difficult. Furthermore, the lack of floristic elements in the understory makes it difficult to determine their phytosociology. Indicator and differential species show the orophylous character of such forest formations: Juniperus sabina, Astragalus granatensis, Thymus leptophyllus, etc. High mountain pastures, favored by human intervention, clearly have

Table I. Lonicero xylostei-Pinetum salzmannii (Gamisans and Gruber, 1988) (subassociation genistetosum patentis; Regato, 1992).

Character- and differential species of the association:

Pinus nigra subsp salzmanni

Lonicera xylosteum

Helleborus foetidus

Differential species of subas genistetosum patentis: Genista patens

Lathyrus filiformis

Juniprus oxycedrus

Juniperus phoenicea

Thalictrum tuberosum

Differential species vs Violo-Quercetum faginae:

Avenula pratensis

Valeriana montana

Juniperus communis

Prunella grandiflora

Pteridium aquilinum

Character-species of Aceri-Quercion:

Acer opalus subsp granatensi

Paeonia officinalis subsp humil

Viola willkommi

Character-species of Quercetalia pubescentis:

Buxus sempervirens

Amelanchier ovalis

Vicia tenuifolia

Primula veris subsp columnae

Sorbus aria

Coronilla emerus

Sorbus domestica
Tanacetum corumbosum \|

Genista hispanica

Cephalanthera rubra

Character-species of Querco-Fagetea:

Hedera helix

Hepatic nobilis

Pinus sylvestris

III Hieracium aggreg murorum IV

II Euphorbia amygdaloides IV

Cruciata glabra III

Brachypodium sylvaticum II

IV Aquilegia vulgaris II

III Sanicula europaea II

III Fragaria vesca II

II Corylus avellana

III Ilex aquifolium I

Geum sylvaticum III

V Species of Querceta ilicis:

III Quercus ilex subsp ballota IV

III Rubia peregrina III

Rhamnus alaternus

111

Other species:

Brachypodim retusum III

Rosmarinus officinalis II

Bupleurum fruticescens II

Euphorbia characias II

Polygala calcarea III 
contributed to the open-structure characteristic of forests of this group.

Group 3: forests located on steepy sites with unstable substrates, and superficial rocks and boulder fields. These conditions favor the establishment of certain subrupiculous taxa, with the subsequent impoverishment of the more sciophilous species. Preferential species are Festuca gauthieri, Amelanchier ovalis, Thalictrum tuberosum, Sorbus domestica, Paeonia officinalis and Lonicera xylosteum. This community has been defined as festucetosum gauthieri (Regato, 1992) subassociation of the climax type Lonicero-Pinetum (table II).

\section{Mesophytic black pine woods of the western sector: groups 4-7}

This grouping comprises 145 sites associated with the most mesophilous conditions of the supra-Mediterranean and Mediterranean mountain belts, between 900 and $1500 \mathrm{~m}$. The main phytoclimatic type is humid nemoro-Mediterranean (VI(IV)2), with high values of thermic continentality (seasonal extremes of temperature). The characteristic substrate is dolomite-limestone, with an abundant appearance of massive dolomite covering the surface of a high plateau or flattopped mountain. In the DCA diagram, sites

Table II. Lonicero xylostei-Pinetum salzmannii (Gamisans and Gruber, 1988) festucetosum gautieri (Regato, 1992).

Character- and differential species of the association:

Pinus nigra subsp salzmannii

Lonicera xylosteum

Helleborus foetidus

Differential species vs Violo-Quercetum valentinae: Juniperus communis

Avenula pratensis

Knautia arvensis

Differential species of subas festucetosum:

Festuca gautieri

Lavandula angustifolia

Teucrium pyrenaicum

Thalictrum tuberosum

Character-species of Quercetalia pubescentis:

Amelanchier ovalis

Ononis aragonensis

Quercus faginea

Tanacetum corymbosum

Berberis vulgaris subsp seroi

Buxus sempervirens

Paeonia officinalis subsp humili

Acer opalus

Lathyrus filiformis

Character-species of Querco-Fagetea:

Pinus sylvestris

Hieracium aggr murorum
Cruciata glabra

Hepatica nobilis

Prunus spinosa

Hedera helix

Species of Ononido-Rosmarinetea:

Euphorbia nicaensis

Lavandula latifolia

Genista scorpius

Aphyllantes monspelliensis

Koeleria vallesiana

Potentilla tabernaemontani

Lotus corniculatus

Medicago suffruticosa

Galium pumilum subsp pinetoru

II

III

II

$\mathrm{V}$

II Other species:

II Quercus ilex subsp ballota II

III Brachypodium phoenicoides III

II Arrhenatherum elatius III

I Bromus erectus II

II Crepis albida III

II Epipactis atrorubens III

I Galium maritimum II

Biscutella valentina III

Sedum sediforme II

III Laserpitium gallicum II

IV Centranthus lecoqii II 
included within these groups are located in both higher and lower left quarters.

Group 4: includes all those black pine forests in the western sector which have the best structure and development and can thus be considered the climax or mature vegetation under these specific ecological conditions. These are mainly located in ubacs, although it should be considered that this might depend on the fact that adrets tend to be managed by humans for cattle-raising and agricultural purposes. The understory is characterized by the abundance of sub-Mediterranean and central-European scrub and herbaceous species. Among indicator and preferential species are Viburnum lantana, Ligustrum vulgare, Buxum sempervirens, Rosa pimpinellifolia, Thalictrum tuberosum, Lathyrus filiformis, Geranium sanguineum and Phyteuma orbiculare. Such pine forests have been described as a new association, Thalictro tuberosi - Pinetum salzmannii (Regato, 1992), which is considered as the potential vegetation type of the high supraand low mountain-Mediterrranean levels on the mountains of the western Iberian Range (Serrania de Cuenca, Montes Universales and western side of Sierra de Gúdar), (table III). The main phytoclimatic type is the nemoro-Mediterranean humid, VI(IV)2.

Group 5: includes those mesophytic black pine forests of a more steppic nature, which are typical of the transitional mountains between the western and eastern sectors. These are situated around the very cold and xeric depression of Teruel. Substeppic nemoral, $\mathrm{VI}(\mathrm{VII})$, is the main phytoclimatic type and limestone-marl substrates prevail. In several sites, the sparse structure of the forest is due to intensive human management. The understory is poorer in subMediterranean species, while species of the bushy formations are more frequently found. Among indicator and preferential species are Astragalus granatensis, Avenula pratensis, Festuca rubra, Scabiosa turolensis, Brachypodium phoenicoides and Avenula bromoides. This can well be considered as a variation of group 4 climatic wood, which has been defined as the subassociation astragaletosum granatensis (Regato, 1992) of the climax type Thalictro-Pinetum (table IV).

Group 6: includes mesophytic black pine forests adapted to steppic conditions. These are typical of the highest areas of plateaus and hilly uplands, which share with the steppic Juniperus thurifera forests. Pine woods are mainly placed on dolomite substrates, while Juniper formations tend to develop in limestone-marl areas. Juniperus thurifera is quite common in the pine wood subcanopy tree layer, where the sub-Mediterranean bushy element becomes rare. Among their indicator and preferential species are Brachypodium sylvaticum, Geum sylvaticum, Lathyrus filiformis, Prunus spinosa, Rosa pimpinellifolia, Hepatica nobilis, Berberis vulgaris, Buxus sempervirens, Thymus bracteatus, etc. This can be considered as a geomorphological variation of the typical mature pine woods of group 4, to more extreme climatic conditions in the upland plains and flat-topped mountains. This formation has been defined as juniperetosum thuriferae (Regato, 1992) subassociation of the climax type Thalictro-Pinetum (table V).

Group 7: includes subrupicolous black pine forests of dolomitic gravity slopes and rocky plains, with abundant dolomite-limestone indicator taxa. This is clearly differentiated in the CCA diagram. The black pine has a very irregular development, and hardly ever constitutes a proper canopy. Indicator and preferential species are Jasonia glutinosa, Juniperus phoenicea, Stipa offneri, Fumana ericoides, Alyssum lapeyrousianum, etc.

\section{Xerophytic pine forests of the western area: groups 8-10}

This grouping comprises 140 sites found in the lowest altitude ranges of the southern and western portion of the Serranía de Cuenca, where the xeric nemoro-Mediter- 
ranean type (VI(IV)1) is the main phytoclimate. Under such climatic conditions, Pinus nigra finds its ecological limit and gives origin to moderately developed formations. These tend to have a sparse structure, mainly due to anthropic action as well as to the subrupicolous features of several sites. Such structure favors a xerothermic nature of the wood understory. Quercus faginea and Quercus ilex subsp ballota are frequently present in the tree layer, as the zone is ecotonal with the woods of such oak species. Among indicator and preferential species, only xerothermic taxa of bushy formations, such as Rosmarinus officinalis, Brachypodium retusum, Juniperus phoenicea, Salvia lavandulifolia, Satureja intricata and Erinacea anthyllis can be found.

Table III. Thalictro tuberosi-Pinetum salzmannii (Regato, 1992).

Character and differential species of the association:

Pinus nigra subsp salzmannii

Thalictrum tuberosum

Lathyrus filiformis

Sorbus aria

V
IV
IV
IV

Differential species vs Cephalanthero-Quercetum fagineae:

Rosa pimpinellifolia

Juniperus communis

Ononis aragonensis

Filipendula vulgaris

Avenula pratensis

Character-species of Aceri-Quercenion:

Acer monspessulanum

Quercus faginea

Bupleurum rigidum

Paeonia officinalis subsp humilis

Character-species of Quercion pubescenti-petraeae:

Phyteuma orbiculare

Leucanthemum vulgare

Rhamnus saxatilis

Campanula rapunculoides

Saponaria ocymoides

Lonicera etrusca

Buxus sempervirens

Sorbus domestica

Helleborus feotidus

Character-species of Quercetalia pubescenti-petraeae:

Amelanchier ovalis

Viburnum lantana

Ligustrum vulgare

Primula veris subsp columnae

Geranium sanguineum

Berberis vulgaris subsp seroi

Tanacetum corymbosum

Vicia onobrycioides

Prunus mahaleb
Character-species of Querco-Fagetea:

\section{Crataegus monogyna}

Hepatica nobilis

Geum sylvaticum

Polygonatum odoratum

Cornus sanguinea

Viola reichenbachiana

Lonicera xylosteum

Aquilegia vulgaris

Corylus avellana

III Brachypodium sylvaticum

III Sanicula europaea

Hedera helix

Cephalanthera rubra

IV Lonicera peryclimenum

III Clematis vitalba

II UImus glabra

III Tilia plathyphyllos

Vicia tenuifolia

Silene nutans

III

IV Species of Aphyllantion:

III Catananche coerulea

II Aphyllantes monspelliensis

Lotus corniculatus

Potentilla tabernaemontani

Anthyllis montana

III

III

III

III

II

II

II

II

II

II

II

I

II

1

1

I

Other species:

Arrhenatherum elatius

Brachypodium phoenicoides

Euphorbia nicaensis

Teucrium chamaedrys

Rubia peregrina

Hippocrepis glauca

Lavandula latifolia

Genista scorpius

Bromus erectus

Koeleria vallesiana
IV

III

III

II

II

IV

III

IV

V

IV

III

III

II

II

II 
The almost complete absence of nemoral species in the understory and the frequent appearance of Quercus species make it very difficult to characterize these ecotonal sites, where Pinus/Quercus mixed forest is most likely their foreseeable forest type.

\section{Xeromesophytic pine forests of the eastern section: groups 11-13}

This grouping includes 33 sites found in the lower elevation areas of the dolomitic ranges

Table IV. Thalictro tuberosi-Pinetum salzmannii astragaletosum granatensis (Regato, 1992).

Character-species of the association:

Pinus nigra subsp salzmannii

Thalictrum tuberosum

Lathyrus filiformis

Differential species of subas astragaletosum:

Astragalus granatensis

Festuca gautieri

Astragalus hypoglottis

Juniperus thurifera

Diff species vs Cephalanthero-Quercetum fagineae: Juniperus communis

Rosa pimpinellifolia

Avenula pratensis

Knautia arvensis

Character-species of Quercetalia pubescentis:

Amelanchier ovalis

Helleborus foetidus

Tanacetum corymbosum

Ononis aragonensis

Leucanthemum vulgare

Silene nutans

Acer opalus

Vicia tenuifolia

Teucrium chamaedrys

Character-species of Querco-Fagetea:

Pinus sylvestris

Crataegus monogyna

Hieracium aggr murorum

Cruciata glabra

Viola reichenbachiana

Rosa nitidula

Hepatica nobilis

Species of Erinacetalia:

Thymus bracteatus

Festuca hystrix

Centaurea pinae

Erinacea anthyllis
Thymus leptophyllus \|

V Potentilla cinerea II

III Polygala calcarea II

II Festuca hystrix II

Juniperus sabina

IV Character-species of Ononido-Rosmarinetea:

II Lavandula latifolia V

III Koeleria vallesiana IV

III Euphorbia nicaensis IV

Potentilla tabernaemontani IV

Aphyllantes monspelliensis III

Sanguisorba minor IV

Thymus vulgaris IV

Genista scorpius II

Scabiosa turolensis IV

Santolina chamaecyparisus III

Salvia lavandulifolia II

Avenula bromoides II

Leuzea conifera III

Catananche coerulea II

Medicago suffruticosa II

Digitalis obscura II

Galium verum II

Other species:

Arrhenatherum elatius V

Bromus erectus IV

Brachypodium phoenicoides IV

Ononis spinosa II

Carex humilis II

Hieracium pilosella II

Campanula hispanica II

Dactylis glomerata II

Brachypodium retusum II

Festuca rubra II

Asperula cynanchica III

Hieracium pilosella II

III Ononis tridentata I

III Biscutella valentina II

II Erysimum grandifolium II 
Table V. Thalictro buterosi-Pinetum salzmannii juniperetosum thuriferae (Regato, 1992).

Character-species of the association:

Pinus nigra subsp salzmannii

Thalictrum tuberosum

Lathyrus filiformis

Differential species of the subas juniperetosum:

Juniperus thurifera

Thymus bracteatus

Berberis vulgaris subsp seroi

Prunus spinosa

Differential species vs Cephalanthero-Quercetum faginae: Juniperus communis

Avenula pratensis

Filipendula vulgaris

Rosa pimpinellifolia

Character-species of Quercetalia pubescentis:

Amelanchier ovalis

Buxus sempervirens

Paeonia officinalis subsp humilis

Quercus faginea

Cephalanthera damasonium

Cephalanthera longifolia

Limodorum abortivum

Rhamnus saxatilis

Acer monspessulanum

Vicia onobrychioides

Leucanthemum vulgare

Orchis mascula

Character-species of Querco-Fagetea:

Geum sylvaticum

Crataegus monogyna

Rosa sicula

Brachypodium syivaticum

Pinus sylvestris

Hieracium aggr murorum

Viola reichembachiana

Hepatica nobilis

Sanicula europaea

Fragaria vesca

Differential species of the com with $G$ mugronensis:

Festuca hystrix

Genista mugronensis

Arenaria obtusiflora

Cerastium brachypetalum
Poa ligulata

$\checkmark \quad$ Ranunculus gramineus $\quad 1$

III Stipa offneri +

III Dianthus hispanicus I

Erinacea anthyllis

III Species of Ononido-Rosmarinetea:

IV Genista scorpius III

IV Lavandula latifolia V

III Euphorbia nicaensis V

Potentilla tabernaemontani IV

Helianthemum cinereum IV

Coronilla minima III

Koelleria vallesiana IV

III Medicago suffriticosa II

III Aphyllantes monspelliensis III

Lotus corniculatus \|

Helianthemum apenninum II

III Sanguisorba minor II

II

II Other species:

II Arrhenatherum elatius V

I Thymus vulgaris IV

I Anthyllis vulneraria I

II Hippocrepis glauca II

II Teucrium chamaedrys III

I Polygala calcarea II

I Trifolium campestre II

II Achillea odorata III

I Erysimum grandiflorum II

Bromus erectus I

Brachypodium phoenicoides I

IV Dactylis glomerata II

IV Thapsia villosa III

V Acinos alpinus II

III Biscutella valentina I

I Carex hallerana II

IV Hieracium pilosella I

II Globularia vulgaris I

I Asphodelus cerasifer II

+ Phlomis lychnitis II

I Marrubium supinum I

Carduus assoi

Eryngium campestre II

II Lithodora fruticosa 1

1 Santolina chamaecyparisus I

II Vicia pyrenaica + 
in the proximity of the coast. Escarpments and canyons are common, producing very heterogeneous site conditions. Group 11 has the most nemoral conditions, and can be considered as a xerothermic variation of the mature black pine woods of the eastern sector, Lonicero-Pinetum subassociation genistetosum patentis (Regato, 1992) (table I). There is a considerable amount of mesophytic taxa in the understory, but with a lower abundance index. The presence of species such as Juniperus oxycedrus, Juniperus phoenicea, Bupleurum fruticescens and Brachypodium retusum indicates their xeromesophytic character.

Groups 12 and 13 are clearly differentiated in the CCA diagram. The former includes the most thermic sites of black pine formations in the Sistema Ibérico, and it should be considered as azonal open communities with the worst growth potential. The latter group comprises the subrupicolous sites, where the canopy hardly exists, and where trees have an irregular distribution over the rocky slopes.

\section{DISCUSSION AND CONCLUSION}

Black pine forests have their ecological optimum between the supra- and mountainMediterranean levels of these dolomite-limestone ranges, under a very cold humid nemoro-Mediterranean continental phytoclimate. Under these conditions, the potential for growth of Pinus nigra is better than that of other species. In the Sistema Ibérico, there are 2 climax communities, the more continental one, Thalictro-Pinetum salzmannii, located in the western part (groups 4-6) and the less continental one, Lonicero-Pinetum salzmannii, located in the eastern part (groups 1, 3 and 11), similar to the black pine woods of the Pyrenees.

The indicator species group of the best sites is a combination of sub-Mediterranean and central-European taxa. Some of the most common characteristics are:
Sorbus aria

Hepatica nobilis

Rosa pimpinellifolia

Lathyrus filiformis

Juniperus communis

Thalictrum tuberosum

Lonicera xylosteum

Primula veris ssp columnae

Viburnum lantana

Sanicula europaea

Amelanchier ovalis

Geum sylvaticum

Buxus sempervirens

Avenula pratensis

Acer opalus ssp granatensis

Brachypodium sylvaticum

These woods, included in $\mathrm{Cl}$ QuercoFagetea (or, Quercetalia pubescentis), represent the ecological optimum (with real nemoral understory conditions and well vertical-structured canopy) of extensive areas that were previously established as potential sites of more xerophytic vegetation (Juniperus thurifera cold steppic woods and Quercus ilex subsp ballota thermic woods).

In these climax communities, we can distinguish 2 site types:

1) Those stands associated with the hilly uplands, where the subcanopy is dominated by the herbaceous layer. The arbustive layer is poor and integrated by the most continental species (Juniperus communis, Rosa pimpinellifolia and Berberis vulgaris subsp serol). This type has the best site quality, particularly over convex reliefs or plains. In the floor of some doline fields, the growth rate of Pinus nigra is very high. Nevertheless, soil conditions in these sites have an unstable equilibrium, often broken by overgrazing and clear-cutting practices. Consequently, important soil losses and problems in tree regeneration will arise. The abundance of Juniperus thurifera in the tree layer can be considered a good index for determining the worst conditions of these kind of sites. Such bad conditions are frequently related to the concave reliefs. 
2) Those stands are associated with the steepy sites on karstic valleys and canyons. The understory is dominated by the arbustive layer. They have a good site quality despite their usually uneven-aged structure. This depends on the heterogeneous conditions of the substrate (rocks, boulder fields, steep slopes). Although the growth potential of black pine is good, the canopy structure may not be uniform. The proportion of subrupicolous taxa can be used as an indicator value of the potential heterogeneous canopy.

The characteritics landform in the Sistema Ibérico is the "cantil-talud" (gravity slope-pediment) system, where intense geomorphologic dynamics occur (Calvo, 1987). The slope retreat maintains the verticality of the cliff. The mixed pine/oak woods growing in pediments with best edaphic conditions are modified by rock avalanches. These dolomitic blocks remove the soil, increasing dolomites and rock surface proportion. Under such conditions, black pine plays an important role in stabilizing and restoring the site conditions.

At the oro-Mediterranean level of the southern mountains (Sierra Javalambre) (group 2), the characteristic cold climate becomes more xeric, tending to steppic conditions. The indicator taxa are dwarf scrubs (eg Juniperus sabina, J hemisphaerica, Prunus prostrata and Astragalus granatense), revealing an open structure of the wood. Nevertheless, these scrubs offer protection to the black pine saplings and to the few nemoral species that only grow below them. Pines have a medium growth potential and, according to Elena-Rosselló and Sánchez-Palomares (1991), their site quality appears to be average.

A high proportion of characteristic species of Ononido-Rosmarinetea bush communities reveal a somewhat extensive understory degradation. In the mountain-Mediterranean level, this usually reveals anthropical degradation (overgrazing; cleaning and thinning processes) and it is difficult to deter- mine its site quality. Highest degradation is revealed with the appearance of Festucopoetalia species (eg Festuca hystrix, Poa ligulata, Arenaria erinacea and Globularia repens), which show strong soil denudation (groups 7 and 10). The black pine usually shows special growth limits with a characteristic table-shaped crown.

The presence of taxa typical of more xerothermic bush communities (Rosmarinoericion) (eg Rosmarinus officinalis, Helianthemum hirtum, Coris monspeliensis and Brachypodium retusum) is considered as being evidence of the lowest site quality. This generally corresponds to sites where Pinus nigra has its ecological limit on the lowest xerothermic slopes (groups 8 and 9). These species are also typical of sites which correspond to rocky or eroded adrets at a higher elevational level.

In the eastern subcontinental sector, the worst site quality corresponds to the lowest sites, where azonal black pine communities are defined, having an open structure and a predominant Quercetea ilicis species understory (group 12).

This phytoecological classification has made it possible to recognize Pinus nigra climax communities, representing the potential vegetation for this mountain region. Once the potential area and ecological optima for Pinus nigra are established, a precise basis for determining the quality of its different site types is available.

When analyzing the TWINSPAN dendrogram, several interesting conclusions were obtained. At the first division level, climax Pinus nigra sites were separated from the azonal ones. In its second level, both site types were divided into 2 groups according to regional climate reasons: the subcontinental types, located in the eastern sector, and the continental types in the western sector. Lower divisions can only be understood when taken into account physiographic factors, showing the landform patterns of the regional geomorphological typical structure. 


\section{ACKNOWLEDGMENTS}

We thank A Iglesias and M Pagliani for their precious help in the translation of the paper, and $A$ Leon for technical assistance. The illustrations were prepared by J De Miguel. This study was supported by an operating grant to PRP by the Forestry Research Institute (CIFOR-INIA) of Spain.

\section{REFERENCES}

Allue-Andrade JL (1990) Atlas fitoclimático de España. Taxonomías INIA, Madrid

Bolos O de, Vigo J, Masalles RM, Ninot JM (1990) Flora manual dels Països Catalans. Ed Pòrtic, Barcelona, $1245 p$

Braun-Blanquet J (1951) Pflanzensoziologie. Grunzüge der Vegetationskunde. Springer Verlag, Vienna

Cajander AK (1926) The theory of forest types. Acta For Fenn 29, 1-108

Calvo A (1987) Geomorfología de laderas en la montaña del Pais Valenciano. Ed Alfons el Magnànim, Inst Val d'Est ilnv, $301 \mathrm{p}$

Carleton TJ (1980) Vegetation of the boreal forests south of James Bay: non-centered component analysis of the vascular flora. Ecology 61, 1199-1212

Castroviejo S et al (eds) (1986-1993) Flora lbérica. Vols I-IV. Real Jardín Botánico, CSIC, Madrid

Daget PH (1977) Le bioclimat mediterranéen : analyse des formes climatiques par le système d'Emberger. Vegetatio 34, 87-103

Elena-Rosselló R, Sánchez-Palomares O (1991) LoS pinares españoles de Pinus nigra Arn: sintesis ecológica. Mon INIA no 81

Gamisans J, Gruber M (1988) Els boscos de pinassa (Pinus nigra subsp salzmannii) als Pirineus catalans i est-aragonesos. In: Homenaje a P Montserrat, Monografias del I Pirenaico de Ecologia Jaca 4, 543552 Jaca

Gamisans J, Gruber M, Regato P (1991) Les forêts de Pinus nigra subsp salzmannii des Pyrénées Aragonaises. Lazaroa 12, 147-151

Gandullo JM (1974) Ensayo de evaluación cuantitativa de la insolación en función de la orientación y de la pendiente del terreno. An INIA Ser Rec Nat 1, 96-107

Gauch HG (1982) Multivariate analysis in community ecology. Cambridge University Press

Gaussen $\mathrm{H}$ (1945) Carte de la végétation de la France. CNRS, Perpignan, France

HIII MO (1979) TWINSPAN. A Fortram program for arranging multivariate data in an order 2-way table by classification of the individuals and attributes. Cornell Univ, New York, NY, USA

Hill MO, Gauch HG (1980) Detrended correspondance analysis: an improved ordination technique. Vegetatio $42,47-58$
Jeglum JK, Arnup RW, Jones RK, Pierpoint G, Wickware GM (1982) Forest ecosystem classification in Ontario's Clay Belt: a case study. Symposium on Artificial Regen Conif Upper Grt Lakes Region, Green Bay, WI, USA

Jones RK (1984) Site classification in Ontario. Proceedings of the Symposium Forest Land Classification: Experience, Problems, Perspectives, WI, USA

Kotar J (1984) Habitat-type classification system in Michigan and Wisconsin. Proceedings of the Symposium Forest Land Classification: Experience, Problems, Perspectives, WI, USA

Maycock PF (1960) The phytosociology of boreal conifer hardwood forests of the Great Lakes Region. Ecol Monogr 30, 1-34

Monserud RA (1977) Problems with site index: an opinionated review. In: Ecological classification of forest land in Canada and Northwestem USA, Vancouver, BC

Pfister RD (1977) Ecological classification of forest land in Montana and Idaho. Proceed ecological classification of forest land in Canada and Northwestern USA. Can Inst For 329-357

Quezel P, Barbero M (1988) Signification phytoécologique des peuplements naturels de Pin de Salzmann en France. Ecologia Mediterranea XIV, 41-63

Regato $P$ (1992) Caracterización florística y ecológica de los bosques de Pinus nigra subsp salzmannii del Sistema lbérico. PhD thesis

Regato P, Genova M, Gomez F (1992) Las representaciones relictas de Pinus nigras Arnold en el Sistema Central español. Bol R Soc Esp Hist Natl (Sec Biol) $88,63-71$

Rivas-Goday S (1946) Dos plantas cavanillesianas. An de/ Jardín Botánico de Madrid, Tomo VI, Vol II, 397-420

Sánchez-Palomares $O$, Elena-Rosselló R, Carretero $P$ (1990) Caracterización edáfica de los pinares autóctonos españoles de Pinus nigra Arn. Com INIA, serie Rec Nat no 55

Ter Braak CJF (1988) CANOCO - an extension of DECORANA to analyze species-environment relationships. Vegetatio 75, 159-160

Tutin TG, Heywood VH, Bruges NA, Valentine DH, Walters SM, Webb DA (1964-1980) Flora Europaea. 5 Vols. Cambridge Univ Press

Van Der Maarel E (1981) Some perspectives of numerical methods in syntaxonomie. In: Syntaxonomie (H Dierschke, ed), J Cramer, Vaduz, 77-93

Walter $\mathbf{H}$ (1968) Die Vegetation der Erde. Band II: die gemässigten und arktischen Zonen. Gustav Fischer Verlag, Stuttgart

Willikomm M (1844) Botanische Berichte aus Spanien. Botanische Zeitung 2, 721-728

Willkomm M (1852) Wanderungen durch die nordöstlichen und centralen Provinzen Spaniens. Reiseerinnerungen aus dem Jahre 1850 (Zweiter Theil). Urnold Buchhandlung, Leipzig

Willkomm M (1896) Die Vegetation der Erde 1: Grundzüge der Pflanzerverbreitung auf der lberische Halbinsel. W Engelman Verlag, Leipzig 